\title{
A STUDY OF TOURISTS' SAFETY IN THE AHANTA WEST DISTRICT IN GHANA
}

\author{
Nicholas Imbeah, MSc, PhD student ${ }^{1}$ \\ Faculty of Economics \& Social Sciences, Szent Istvan University
}

\begin{abstract}
Issues of tourists' safety are gaining grounds in Ghana especially in the Ahanta West District in the Western Region where Ghana discovered commercial crude oil in Cape Three Points in 2007 and started drilling in 2010. Using purposive sampling method, observation, interviews and questionnaires, this study sought to examine the extent to which tourists perceive their own safety in this destination which is old but now renewed tourist destination due to the oil find in Ghana. Welcoming and friendly atmosphere to tourists was indicative of a safe and a secured destination for tourists. The display of globalization showed in the form of 'glocalization' in this destination. There is a conflict between land use for agricultural purposes and tourist facilities since the predominant cash crop in this area is oil palm, hence a threat to agricultural sustainability. It is recommended that the security agents should as a matter of urgency put in place the appropriate structures in this tourist destination and farming area for safety.
\end{abstract}

Keywords: glocalization, Ahanta, Ghana

JEL code: Z32

\section{INTRODUCTION}

Personal safety of tourists at the destination is relevant to tourists and destination managers and therefore the perceived and actual risk associated with travel and tourism has made safety and security very critical in the promotion of tourism (Mopeli, 2009). The subject of safety and security has become more imperative not only for the host-community, but also for the tourist who is a guest (Cavlek, 2002) in a new environment. As Mansfeld and Pizam (2006) opined, peace, safety and security are the three prerequisites for thriving tourism development in every destination.
The tourism sector in Ghana has remained as a steady contributor to economic growth and development. According to Institute of Statistical, Social \& Economic Research - ISSER (2017), tourism has been a major source of foreign exchange, employment and government revenue in Ghana. In the report of World Travel and Tourism Council (WTTC), in 2016, travel and tourism generated a lot more of tourist receipts which was $10.2 \%$ of global GDP and 292 million jobs, equivalent to 1 in 10 jobs in the global economy. The contribution of the tourism sector in 2016 to total employment, both direct and indirect was $5.9 \%$, representing 693,000 jobs. In the assessment of ISSER (2017), tourism arrivals were

\footnotetext{
${ }^{1}$ Corresponding author: Pater Karoly 1, SZIE Hostel, H-2100 Gödöllö, Hungary, nicholas.imbeah@tpoly.edu.gh, +36702229773
} 
Proceedings of the 2018 International Scientific Conference 'Economic Sciences for Agribusiness and Rural Economy' No 2, Warsaw, 7-8 June 2018, pp. 335-339

Table 1. Tourism indicators in Ghana in 2009-2016

\begin{tabular}{|l|c|c|c|c|c|c|c|c|}
\hline Indicator & 2009 & 2010 & 2011 & 2012 & 2013 & 2014 & 2015 & 2016 \\
\hline $\begin{array}{l}\text { Arrivals } \\
\text { (in thous.) }\end{array}$ & 802.8 & 931.2 & 1080.20 & 903.30 & 993.60 & 1093.0 & 1202.2 & 1322.5 \\
\cline { 1 - 7 } $\begin{array}{l}\text { Receipts } \\
\text { (USD million) }\end{array}$ & 1615.20 & 1875.00 & 2178.9 & 1704.7 & 1876.9 & 2066.5 & 2275.2 & 2505.5 \\
\hline \multicolumn{7}{|c|}{ Gross contribution to GDP } \\
\cline { 1 - 7 }
\end{tabular}

Source: Ghanaian Ministry of Tourism, Arts and Culture (2012); Ghana Tourism Authority (2016).

estimated at 1,322,500 in 2016 representing a $10 \%$ increase from 2015 as shown in the TABLE 1 below. Also, as shown in Table 1, revenue from tourism also went up by approximately 10\% from USD 2,275.2 million in 2015 to USD $2,505.5$ million in 2016 .

\section{THEORETICAL BACKGROUND}

Appaw-Agbola and Dehlor (2011) propose that tourism has emerged as one of the fastest growing industries, averaging about $4 \%$ per annum worldwide. They proposed that though there are major destinations in the developed countries, a number of developing countries have also become major points of destination. In Africa, such major destinations include Kenya, Mauritius, Zimbabwe, South Africa and Ghana (Appaw-Agbola and Dehlor, 2011). Tourism in Ghana has become a major socio-economic activity and one of the most important and fastest growing sectors of the Ghanaian economy (Dorkenoo, 2013). The perceived risk associated with travel and tourism has made safety issues come to the lime light in many studies in tourism promotion (Boakye, 2011) especially in the developing countries after the September, 11 disaster in USA where safety was supposed to be the best. This study sought to identify the perceptions tourists have about safety in the Ahanta West District which houses the recently oil find area at the west of Cape Three Points. For this purpose both primary and secondary data are used in the discussion. The adopted and modified model attempts to show how safety at the tourist destination has become integral among tourism components termed by the research as shown below in Figure 1 as '4-DPC' (Four destination product components) namely: physical products, programmes, people and packages.

\section{Destination management}

In the opinion of Morrison (2012), destination management can be defined as the coordination and integration of all the elements of the tourist destination mix (physical products, programmes, people and packages) in a particular geographic area based upon a defined tourism strategy and plan.

Physical products include items like attractions, facilities, transportation and other infrastructure at the tourist destination and these attractions play the central role of pulling and drawing tourists to the destination (Vengesayi, 2003) and one of the reasons of visiting a place (Kamra and Chand, 2006). Events and festivals are put together for tourists and well designed and promoted programmes share the same role with the physical products and their safety conditions can determine the numbers of tourists.

The local people provide the hospitality resources as the hosts and providers of personal services. Hospitality of the residents is an asset to tourism development and this has been the bedrock for tourism development in Ghana especially when it comes to hostguest interaction (Boakye, 2011; Imbeah, Hodibert and Amankwa, 2016). It is also observed in Ghana that hospitality can be classified as both tourist product and safety measure since the personnel who offer the tourist services display the nature, values and 


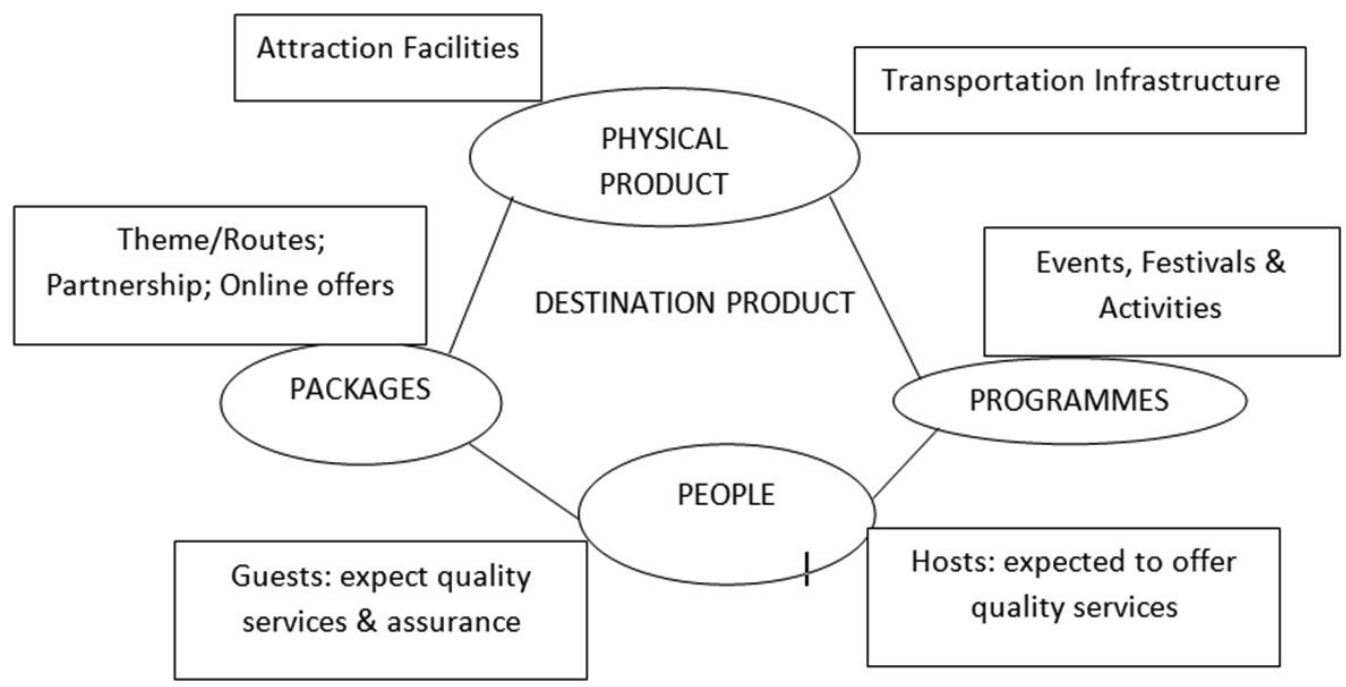

Figure 1. Four destination product components (4-DPC)

Source: adopted and modified from Morrison (2012).

hospitality of the host community. Packages are put together by tour operators, travel agencies and other related agencies, and merge many elements of the total travel experience and satisfaction and these draw tourists to destinations as proposed by Imbeah (2011) and Imbeah and Odoom (2016). In all this, safety is crucial in the operator's motive to make profit and the tourists' motivation to travel.

Figure 1 which is termed '4-DPC' summarizes the components under 2.1.1 and 2.1.2; that destination product is made of physical product, programmes, people and packages which are accessed by tourists at a destination. Each of these destination products has various and viable elements which are either enjoyed or offered for sale by the tour operators to the tourists.

\section{MATERIALS AND METHODS}

A survey, involving a sample of tourists to Ahanta District tourist destination namely, namely Busua Beach, Egyambra Crocodile Pond, Cape Three Points, Dixcove, Akwidaa and Princess Town rendezvous sessions were undertaken. Also, interview with the Ghana Police Service and some literature retrieval from Ghana Tourism Authority (GTA) in Takoradi were conducted. The data collection was done on
1 July 2015 during the peak tourist season in Ghana from June to early September. A purposive sampling technique which was non probability sampling procedure was adopted because the target population was made of tourists. Purposive sampling was used to select these areas because they are possible sites most tourists could be intercepted easily. Research instruments used were: questionnaire was used for the tourists and interview guide was used for the Ghana Police Service. Observation was also keenly applied during the data collection. Research assistants were recruited and trained to help in the questionnaire administration. Meetings were arranged with the management of Ghana Police Service for interview at their offices.

\section{RESULTS AND DISCUSSION}

\section{Origin of respondents}

The study also showed that Europeans were the majority (17 respondents representing $42.5 \%$ ) of the sampled respondents. This was followed by Americans who were 10 representing $25 \%$ of the total sampled respondents. Australians were the least recorded with only one respondent. The number of Asians and Africans except Ghanaians were the same, 6 respondents (representing 15\%) each. This might confirm the 
observation made by Frimpong-Bonsu (2015) that Europeans are the most generating tourists to Ghana. However, the study indicated that, there was a down turn in the arrivals from Africa and Asia while arrivals from Europe and America are still high as per the arrivals at least in this particular district.

\section{Discussion of tourists' perception about safety}

As revealed in Table 2, 45\% of the respondents strongly agreed and 50\% agreed that uncontrolled unemployment is a major cause of tourism offenses and has the propensity to create unsafe ambience for recreational activities and the remaining 5\% disagreed with that notion. Though there was an evidence of uncontrolled offenses situation in this destination, it was not a cause for bother for tourist safety. As shown in Table 2, some of the reasons for feeling unsafe are: overcrowding in facilities, lack of good policing practice, very high cost of living, poor publicity about tourism crime and poor management of tourism facilities.

Ghana Tourism Authority official in Takoradi, said that, 'at the beaches in the District, you always find foreigners mainly Afro-Americans dressed like the natives and even eating the food of the locals while on vacation. You see them freely enjoying the beach facilities without any safety problem and this is manifestation of globalization'. The popular beach is Busua Beach Resort. However, as a result of the presence of serene ambience for vacation in the District, 'glocalization' an aspect of globalization is real. Reisinger (2009) proposed that 'glocalization' is the result of the relationships between the global 'tourists' and the local 'residents'. In the interaction with the Ghana Police Service boss, DSP, it was revealed that, the district is 'fairly a friendly and secured destination'. The days during which the beaches are highly patronized are: Independence Day - 6th of March; Republic Day - 1st of July; Workers' Day - 1st of May; Easter Mondays; and New Year Day - 1st of January. The police intensify patrols at the beaches during holidays to provide adequate security for holiday makers. Majority of the respondents proposed that the presence of police personnel in tourists' areas indicated and enhanced a safe and a secured destination for tourists and where there was a provision of a welcoming and friendly atmosphere to visitors, tourists also felt safe and secure.

\section{Recommendations}

From the foregoing, it is recommended that the GTA should quickly take opportunity of calm tourist destination to establish the necessary structures such as engaging the immediate tourism agencies like the local tour guides and form a team made of guides, Ghana Police Service and Ghana Fire Service should help educate and maintain safety in this destination. It is again recommended that, service providers should be

Table 2. Unsafe conditions-distribution of tourists' reasons

\begin{tabular}{|l|c|c|c|c|c|}
\hline Reasons & $\begin{array}{c}\text { SA } \\
\text { (strongly } \\
\text { agree) }\end{array}$ & $\begin{array}{c}\text { A } \\
\text { (agree) }\end{array}$ & $\begin{array}{c}\text { N } \\
\text { (neutral) }\end{array}$ & $\begin{array}{c}\text { D } \\
\text { (disagree) }\end{array}$ & $\begin{array}{c}\text { SD (strongly } \\
\text { disagree) }\end{array}$ \\
\hline Uncontrolled unemployment & 45 & 50 & 0 & 5 & 0 \\
\hline Overcrowding in facilities & 10 & 17.5 & 0 & 52.5 & 20 \\
\hline Lack of good policing practice & 0 & 5 & 0 & 82.5 & 12.5 \\
\hline Very high cost of living & 15 & 27.5 & 30 & 15 & 12.5 \\
\hline Poor publicity about tourism crime & 0 & 10 & 42.5 & 20 & 27.5 \\
\hline Poor management of the facilities & 2.5 & 15 & 27.5 & 50 & 5 \\
\hline Uncontrolled crime situation & 0 & 0 & 2.5 & 7.5 & 90 \\
\hline
\end{tabular}

Source: fieldwork and Results of Tourists' Perception about Safety (2015). 
advised by the GTA on how to treat their clients as far as harassment and security of tourists are concerned. Most tourists become victims of behaviour intended to disturb or upset or make them insecure because they are unaware of such issues and some have little knowledge about them in the country. Finally, the Ghana Tourism Authority needs to organize seminars and training programmes for service providers and the general public to make them understand what they may lose if security and harassment of tourists are not managed properly and to encourage friendly behaviour.

\section{CONCLUSIONS}

The research revealed that tourists generally perceive Ghana to be safe even though few of them were once victims to crime situations; they would still recommend the destination for others and would even want to visit again. Agriculture is the major economic activity in the District and the predominant cash crop is oil palm. However, one notable challenge is the competition between the use of land for rubber plantations and use of land for cultivation of food crop. Also, there is also an increasing demand for land for other non-agricultural activities like tourism and hotel facilities in the district especially in the wake of the oil find in the region and its subsequent drilling in 2010 .

\section{REFERENCES}

1. Appaw, A.M., Dehlor, J. (2011). Tourism development in local communities: As a community development approach. Journal of America Science, 6, pp. 155-161.

2. Boakye, A.B. (2011). Tourists' views on safety and vulnerability: A study of some selected towns in Ghana. Tourism Management, 33, pp. 327-333.

3. Cavlek, N. (2002). Tour Operators and Destination Safety. Journal of Tourism Research, 29 (4), pp. 457$-534$.
4. Dorkenoo, B.F. (2013). Exploring the Way Forward for Ghana's Tourism Industry through Domestic Tourism. Ashesi University College, Ghana.

5. Fieldwork and Results of Tourists' Perception about Safety (2015). Survey Data Collection, Ghana.

6. Frimpong-Bonsu, W. (2015). Diagnostic Study of Tourism in Ghana. African Center for Economic Transformation, Accra.

7. Imbeah, N. (2011). Using Festivals to Promote Tourism: A Case Study of 'Aboakyer' \& 'Bakatue' in the $\mathrm{C} / \mathrm{R}$ of Ghana. Distance Forum: A Multidisciplinary Book of Scholarly Articles, 1, pp. 142-159.

8. Imbeah, N., Hodibert, V.A., Amankwa, R. (2016). Residents' Perception of Host- Guest Interaction about Kwahu Easter Festival (FEK) as Festival Tourism. Africa Development and Resources Research Institute (ADRRI) Journal, 25, 9 (3), pp. 1-16.

9. Imbeah, N., Odoom, C.E. (2016). Afahye as a Tourism Product - The Case of Oguaa Fetu Afahye in the Central Region of Ghana. Distance Forum: A MultiDisciplinary Journal of the Arts \& Humanities, 4, pp. 109-127.

10. Institute of Statistical, Social \& Economic Research (2017). The State of the Ghanaian Economy in 2016. ISSER, University of Ghana, Legon.

11. Kamra, K.K., Chand, M. (2006). Basics of Tourism: Theory, Operation and Practice. Kanishka Publishers, New Delhi.

12. Mansfeld, Y., Pizam, A. (2006). Toward a theory of tourism security. Tourism Management, 31 (6), pp. 855-886.

13. Mopeli, M.J. (2009). Impacts of tourists' perceptions of safety and security of tourism marketing of Mpumalanga (master's thesis). Durban University of Technology, Durban.

14. Morrison, A.M. (2012). Marketing and Managing Tourism Destinations. Routledge, London.

15. Reisinger, Y. (2009). International Tourism, Cultural and Behaviour. Butterworth-Heinemann, Amsterdam.

16. Vengasayi, S. (2003). A conceptual model of tourism destination competiveness and attractiveness. Conceptual papers. In: ANZMAC 2003 Conference Proceedings, Adelaide 01-03.12.2003, pp. 637-647. 